\title{
Estimation of Serum Magnesium level among Patients with Bronchial Asthma in Erbil -Iraq
}

Kamaran Mahmud Saidoka (MBChB, HD) ${ }^{1}$, Salam Naser Zangana (MB, ChB, DM, CABMS, FICMS $)^{2}$ and Rebaz Tahir Lak (MBChB, FIBMS (CM) $)^{3}$

\section{Abstract}

Background:Bronchial asthma is a common chronic respiratory disease worldwide. Although magnesium ( $\mathrm{Mg}$ ) deficiency has been shown to play a role in exacerbation of asthma, the exact prevalence of hypomagnesaemia in asthma is not clear.

Objective: To estimate the serum Mg levels in bronchial asthma patients and compare them with healthy population and to evaluate the prevalence of hypomagnesaemia among them.

Patients and Methods: A cross-sectional study was carried out in the respiratory unit of Rizgary Teaching Hospital involving 80 adult patients with chronic asthma (group I) and 80 healthy adult controls (group II). Serum magnesium level was measured in all the participants.

Results: Hypomagnesaemia was detected in $20 \%$ of the asthmatic patients when compared to controls $(0 \%)(\mathrm{p}=0.001)$. No significant association was detected between magnesium status and type of asthma $(\mathrm{p}=0.59)$. There was a statistically significant stage-wise decline in serum levels of $\mathrm{Mg}$ with increase in severity of asthma $(\mathrm{p}=0.02)$. Patients with severe asthma had the highest prevalence of hypomagnesaemia (45.5\%) in comparison to mild and moderate cases $(\mathrm{p}=0.001)$. No significant associations were detected between the level of magnesium and the number of medications that the patients used, corticosteroids use, and theophylline therapy ( $\mathrm{p}=0.06,0.17$, and 0.08 , respectively). Hypomagnesaemia was significantly correlated with the duration of asthma $(\mathrm{p}=0.04)$.

Conclusion: Hypomagnesaemia is more prevalent in chronic asthmatics than non-asthmatics. Hypomagnesaemia was significantly correlated with severity and duration of asthma.

Keywords: Chronic asthma, Magnesium, Hypomagnesaemia

Corresponding Author: dr_salam2003@yahoo.com

Received: $6^{\text {th }}$ March 2019

Accepted: $7^{\text {th }}$ April 2019

\footnotetext{
${ }^{1,3}$ Kurdistan Board of Medical Specialties (KBMS)- Erbil-Iraq.

${ }^{2}$ College of Medicine-Hawler Medical University-Erbil-Iraq.
}

\section{Introduction}

Magnesium (Mg) is the eleventh most abundant element in the human body and the second most common intracellular cation [1]. Total body $\mathrm{Mg}$ is about 25 gram, $60 \%$ of it is in the bones, $39 \%$ intracellular $(20 \%$ in skeletal muscle), and only $1 \%$ is in the extracellular fluid [2]. $\mathrm{Mg}$ is a cofactor in more than 300 enzyme systems that regulate 
diverse biochemical reactions in the body, including muscle and nerve function, blood glucose control, and blood pressure regulation[3]. $\mathrm{Mg}$ also intervenes in calcium transport mechanisms and so, it plays an important role in contraction and relaxation state of bronchial smooth muscle. $\mathrm{Mg}$ has several actions on bronchial airways including bronchodilation, anticholinergic effects, and stabilization of mast cells $[4,5]$. Hence, $\mathrm{Mg}$ deficiency leads to increased contractility of bronchial smooth muscle and increased airways hyperreactivity $[6,7]$.

Bronchial asthma is a chronic condition characterized by recurrent bronchospasm resulting from airways inflammation and hyperreactivity of tracheobronchial tree [8]. Asthma is widely distributed all over the globe, and affects nearly 334 million people, with a prevalence of about $10-12 \%$ in adults [9]. Although many studies demonstrated high prevalence of hypomagnesaemia in both acute and chronic asthma when compared with non-asthmatic persons $[10,11]$, other studies have not confirmed this fact $[12,13]$. Up to our knowledge, there was no previous study done regarding the same subject in Erbil city. The current study was done to estimate the levels of serum $\mathrm{Mg}$ in patients with chronic bronchial asthma, and to evaluate the prevalence of hypomagnesaemia among them.

\section{Patients and Methods}

This observational, cross-sectional study was conducted in the respiratory unit at Rizgary teaching hospital in Erbil city, Iraq, between January 2018 and September 2018.
The study included 160 adults distributed as 80 patients with chronic bronchial asthma (group I) and 80 healthy individuals as controls (group II). The inclusion criteria were: patients with stable chronic bronchial asthma with no history of exacerbation at the time of presentation or within last week, adults (age $\geq 18$ years) of both genders, and non-smokers. The exclusion criteria were: medical disorders (like diabetes mellitus, hypertension, ischemic heart disease, diarrhea, and chronic kidney disease), patients on diuretic therapy, patients taking multivitamins, alcoholism, pregnancy and lactation. All patients were evaluated with detailed history (each patient was questioned regarding their inhaled and oral medications), general survey and examination of the respiratory system. Two milliliter of venous blood sample without anticoagulation was taken from all participants, and then centrifuged for 10 minutes. The serum was taken for analysis using ELISA kit (Microwell ELISA, Diagnostic Automation Inc., USA). According to the laboratory values of our hospital, the reference range for total $\mathrm{Mg}$ level was $1.6-2.6 \mathrm{mg} / \mathrm{dl}$ in both male and female adults. Serum $\mathrm{Mg}$ level below 1.6 $\mathrm{mg} / \mathrm{dl}$ was considered as hypomagnesaemia. Severity of persistent asthma (mild, moderate and severe) was assessed on the basis of GINA guidelines [9]. The relationship of hypomagnesaemia with severity of asthma, duration of asthma, types of medication use, and total number of medication used were assessed.A verbal informed consent was obtained from all the participants in the study 
and the protocol was approved by the Ethics Committee of the College of Medicine of Hawler Medical University.

\section{Statistical analysis}

The statistical package for social sciences (SPSS, version 19) was used for data analysis. Chi square test of association was used to compare proportions. Fisher's exact test was used when the expected count of more than $20 \%$ of the cells of the table was less than 5 . P-value of $\leq 0.05$ was considered as statistically significant.

\section{Results}

As shown in table 1 , females constitute 70 $\%$ of the asthmatic patients and $62.5 \%$ of the control group with no statistically significant difference between both groups regarding gender $(p=0.31)$. The means of age of both study groups show also no significant difference $(p=0.92)$. In addition, the table shows a statistically significant association between study group and magnesium status. All participants in control group had a normal $\mathrm{Mg}$ level, in contrary $20 \%$ of asthmatic patients had hypomagnesaemia $(\mathrm{p}=0.001)$.

Table (1): Some demographics and Mg levels of both study groups.

\begin{tabular}{|c|c|c|c|c|c|}
\hline & \multirow{2}{*}{\multicolumn{2}{|c|}{$\begin{array}{c}\text { Group I } \\
\text { Asthmatic } \\
\text { patients }(n=80)\end{array}$}} & \multicolumn{2}{|c|}{$\begin{array}{l}\text { Group II } \\
\text { Controls }(n=80)\end{array}$} & \multirow[t]{3}{*}{$\begin{array}{c}\mathrm{P} \\
\text { value }\end{array}$} \\
\hline & & & \multirow{2}{*}{ No. } & \multirow{2}{*}{$\%$} & \\
\hline & No. & $\%$ & & & \\
\hline $\begin{array}{l}\text { Male } \\
\text { female }\end{array}$ & $\begin{array}{l}24 \\
56 \\
\end{array}$ & $\begin{array}{l}30 \\
70 \\
\end{array}$ & $\begin{array}{l}30 \\
50 \\
\end{array}$ & $\begin{array}{l}37.5 \\
62.5 \\
\end{array}$ & 0.31 \\
\hline Age (years) \pm SD & \multicolumn{2}{|c|}{$40.16 \pm 15.48$} & \multicolumn{2}{|c|}{$39.93 \pm 14.53$} & 0.92 \\
\hline "Serum Mg (mg/dl) & \multicolumn{2}{|c|}{$1.99 \pm 0.29$} & \multicolumn{2}{|l|}{$2 \pm 0.23$} & 0.85 \\
\hline $\begin{array}{l}\text { Patients with } \\
\text { hypomagnesaemia }\end{array}$ & 16 & 20 & 0 & 0 & 0.001 \\
\hline
\end{tabular}

Table(2) reveals that there was a nonsignificant association between magnesium status and type of asthma $(\mathrm{p}=0.59)$. The level

majority of patients regardless whether they were of persistent or intermittent type of asthma. of serum magnesium was normal in the

Table (2): Relationship between magnesium status and type of asthma.

\begin{tabular}{|c|c|c|c|c|}
\hline \multirow{2}{*}{\multicolumn{2}{|c|}{ Type of asthma }} & \multicolumn{2}{|c|}{ "Magnesium status } & \multirow[b]{2}{*}{ Total } \\
\hline & & Hypomagnesaemia & Normal & \\
\hline & \multirow[t]{2}{*}{ Intermittent } & 3 & 16 & 19 \\
\hline & & $15.8 \%$ & $84.2 \%$ & $100 \%$ \\
\hline & \multirow[t]{2}{*}{ Persistent } & 13 & 48 & 61 \\
\hline & & $21.3 \%$ & $78.7 \%$ & $100 \%$ \\
\hline \multirow{2}{*}{\multicolumn{2}{|c|}{ Total }} & 16 & 64 & 80 \\
\hline & & $20 \%$ & $80 \%$ & $100 \%$ \\
\hline
\end{tabular}


Although mean serum magnesium levels were within the normal range in all grades of asthma, Table(3) shows a statistically significant stage-wise decline in mean serum levels of $\mathrm{Mg}$ with increase in severity of asthma $(\mathrm{p}=0.02)$.

Table (3): Relationship between the means of magnesium levels and grades of asthma.

\begin{tabular}{|l||l||l||l||}
\hline $\begin{array}{l}\text { Grades of } \\
\text { asthma }\end{array}$ & Cases $(\mathrm{n}=80)$ & $\begin{array}{l}\text { Serum Mg level } \\
(\text { mean } \pm \text { SD) }\end{array}$ & P value \\
\hline \hline mild & 8 & $2.05 \pm 0.23$ & \multirow{2}{*}{0.02} \\
\hline \hline moderate & 50 & $2.02 \pm 0.38$ & \\
\hline \hline severe & 22 & $1.85 \pm 0.34$ & \\
\hline
\end{tabular}

According to Table (4), there was a severe asthma had the highest prevalence of significant relationship between magnesium Hypomagnesaemia (45.5\%) in comparison to status and grades of asthma. Patients with mild and moderate cases $(\mathrm{p}=0.001)$.

Table (4): Prevalence of hypomagnesaemia in different grades of asthma.

\begin{tabular}{|c|c|c|c|c|}
\hline \multirow{2}{*}{\multicolumn{2}{|c|}{ Grade of asthma }} & \multicolumn{2}{|c|}{ Magnesium status } & \multirow[b]{2}{*}{ Total } \\
\hline & & Hypomagnesaemia & Normal & \\
\hline & \multirow[t]{2}{*}{ Mild } & 2 & 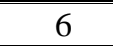 & 8 \\
\hline & & $25 \%$ & $75 \%$ & $100 \%$ \\
\hline & \multirow[t]{2}{*}{ Moderate } & 4 & 46 & 50 \\
\hline & & $8 \%$ & $92 \%$ & $100 \%$ \\
\hline & \multirow[t]{2}{*}{ Severe } & 10 & 12 & 22 \\
\hline & & $45.5 \%$ & $54.5 \%$ & $100 \%$ \\
\hline \multirow{2}{*}{\multicolumn{2}{|c|}{ Total }} & 16 & 64 & 80 \\
\hline & & $20 \%$ & $80 \%$ & $100 \%$ \\
\hline
\end{tabular}

The findings of Table (5) reveal that there were non-significant associations between the level of magnesium and the number of medications that the patients used, corticosteroids, and theophylline therapy ( $\mathrm{p}=0.06,0.17$, and 0.08 , respectively).
There was a significant relationship between duration of the asthma and magnesium levels, i.e. patients with hypomagnesaemia had asthma for a longer duration of time compared with normomagnesaemia asthmatics $(\mathrm{P}=0.04)$. 
Table (5): Relationship between magnesium status and the medications used by asthmatics.

\begin{tabular}{|c|c|c|c|c|}
\hline Variables & $\begin{array}{c}\text { Hypomagnesaemia } \\
\mathrm{N}=16\end{array}$ & $\begin{array}{c}\text { Normomagnesaemia } \\
\mathrm{N}=64\end{array}$ & $\begin{array}{l}\text { Total } \\
\mathrm{N}=80\end{array}$ & $\begin{array}{l}\mathrm{P} \\
\text { value }\end{array}$ \\
\hline $\begin{array}{l}\text { Total medication } \\
\quad<3 \\
\geq 3\end{array}$ & $\begin{array}{c}1 \\
15\end{array}$ & $\begin{array}{l}18 \\
46\end{array}$ & $\begin{array}{l}19 \\
61\end{array}$ & 0.06 \\
\hline $\begin{array}{c}\text { Use of } \beta \text {-agonist } \\
\text { Yes } \\
\text { No }\end{array}$ & NS & NS & NS & NS \\
\hline $\begin{array}{c}\text { Use of steroids } \\
\text { Yes } \\
\text { No } \\
\end{array}$ & $\begin{array}{c}11 \\
5 \\
\end{array}$ & $\begin{array}{l}32 \\
32 \\
\end{array}$ & $\begin{array}{l}43 \\
37 \\
\end{array}$ & 0.17 \\
\hline $\begin{array}{c}\text { Use of THP } \\
\text { Yes } \\
\text { No } \\
\end{array}$ & $\begin{array}{c}13 \\
3 \\
\end{array}$ & $\begin{array}{l}37 \\
27 \\
\end{array}$ & $\begin{array}{l}50 \\
30 \\
\end{array}$ & 0.08 \\
\hline Duration of asthma & $15.56 \pm 7.5$ & $11.09 \pm 7.1$ & & 0.04 \\
\hline
\end{tabular}

\section{Discussion}

The prevalence of hypomagnesaemia in our asthmatic patients was $20 \%$.The present study shows that the asthmatic patients had a significantly low serum magnesium level when compared to the controls. This result is in agreement with the studies done by Shaikh [10], Yuvarajan [11], Ali [14] and many other studies but with variable prevalence. Although the cause of hypomagnesaemia in patients with chronic asthma was not well known [15], it may be multi-factorial. It may be related to low magnesium intake in asthmatics, or increased urinary loss of magnesium as a side effect of therapy with $\beta 2$-agonist, corticosteroids, and theophylline[16,17], or it may be genetically determined[18].

In the current study, there was a high prevalence of hypomagnesaemia in severe asthma $(45.5 \%)$ when compared to other grades ( mild and moderate) and the serum magnesium level was correlated significantly with severity of asthma $(p=0.02)$. These findings are similar to many previous studies done by Shaikh [10], Yuvarajan [11], and Alamoudi [19]. These studies have proved that hypomagnesaemia in asthma is associated with increased incidence of wheeze, impairment of lung function, and increased bronchial hyper-reactivity (BHR). As mentioned before, low magnesium level may enhance calcium movement inside the smooth muscle cell and making the cell more contractile and thus increasing $\operatorname{BHR}[6,7]$. $\mathrm{Mg}$ deficiency may also increase production of acetylcholine in cholinergic nerve endings, increase histamine release from mast cell, increase production of interlukin-1 and 6 , and enhance production of $\operatorname{IgE}[20,21]$. Some studies mentioned that therapeutic and 
dietary supplementation of magnesium has been shown to either reduce the BHR or improve in bronchial responsiveness and quality of life [22].

Although the present study did not reveal any statistically significant relationship of hypomagnesaemia with the use of steroids $(p=0.17)$, it's worth to mention that the $p$ value was so close to be significant with the use of theophylline $(p=0.08)$ and use of $\geq 3$ medications $(p=0.06)$. Regarding the use of $\beta 2$-agonist, the Chi square test was not calculated, as all the patients were on $\beta 2$ agonist.

Some studies have revealed that hypomagnesaemia may be related to the side effect of therapy with $\beta 2$-agonist, corticosteroids, and theophylline[16,17], however, hypomagnesaemia was found to be present in asthmatic patients who were not on treatment with these drugs or even after withdrawal of them[19,23], which is in agreement with the result of our study.

Lastly, the current study showed that hypomagnesaemia was significantly correlated with the duration of asthma $(\mathrm{p}=0.04)$. The duration of asthma was longer in asthmatic patients with hypomagnesaemia compared to those with normal $\mathrm{Mg}$ level. While few previous studies demonstrated no relationship between hypomagnesaemia and duration of asthma [14,24], the current study found such a relationship.

\section{Conclusions}

Hypomagnesaemia is more prevalent in chronic asthmatics than non-asthmatics. Hypomagnesaemia was significantly correlated with severity and duration of asthma.

\section{Recommendations}

Serum magnesium level may serve as a marker of asthma severity. So the level of this analyte should be monitored in asthmatic patients and should be corrected if found low. The cause of hypomagnesaemia in asthma and role of magnesium supplementation in asthmatics is an important field warranting further research. Magnesium rich foods may be encouraged for asthmatic patients.

This study is limited by the small sample size. A larger sample size would help draw more statistically accurate conclusion.

\section{References}

[1]Dietary Supplement Fact Sheet: Magnesium". Office of Dietary Supplements, US National Institutes of Health. 11 February 2016. Retrieved 13 October 2016. [2]Volpe SL. Magnesium. In: Erdman JW, Macdonald IA, Zeisel SH, eds. Present Knowledge in Nutrition. 10th ed. Ames, Iowa; John Wiley \& Sons, 2012:459-74.

[3]Rude RK. Magnesium. In: Ross AC, Caballero B, Cousins RJ, Tucker KL, Ziegler TR, eds. Modern Nutrition in Health and Disease. 11th ed. Baltimore, Mass: Lippincott Williams \& Wilkins; 2012:15975.

[4]Gourgoulianis KI, Chatziparasidis G, Chatziefthimiou A, Molyvdas PA. Magnesium as a relaxing factor of airway smooth muscles. J Aerosol Med 2001; 14 (3): 301- 7.

[5]Saris NE, Mervaala E, Karppanen H, Khawaja JA, Lewenstam A. Magnesium. An 
update on physiological, clinical and analytical aspects. Clin Chim Acta 2000; 294 (1-2): 1- 26.

[6] Dacey MJ. Hypomagnesemic disorders. Crit Care Clin 2001; 17 (1): 155- 73, viii.

[7] Schenk P, Vonbank K, Schnack B, Haber

$\mathrm{P}$, Lehr S, Smetana R. Intravenous magnesium sulfate for bronchial hyperreactivity: a randomized, controlled, double-blind study. Clin Pharmacol Ther 2001; 69 (5): 365- 71.

[8] Agarwal R., Dhooria S., Aggarwal A. N. "Guidelines for diagnosis and management of bronchial asthma: joint ICS/NCCP (I) recommendations"Lung India, 2015. vol.32, no.7, pp. S3-S42.

[9]Global Initiative for Asthma (GINA) : Global Strategy for Asthma Management and Prevention, 2018.

[10]Shaikh M N, Malapati B R, Gokani R, Patel B, Chatriwala M. Serum Magnesium and Vitamin D Levels as Indicators of Asthma Severity. Hindawi Publishing Corporation ,Pulmonary Medicine. 2016, Article ID 1643717, 5 pages .

[11] Yuvarajan S, Ambikapathi P, Reddy V , Kalaikovan B. A study on serum magnesium level in bronchial asthma patients. Indian Journal of Immunology and Respiratory Medicine, January-March 2017;2(1):4-6. [12] Falkner D, Glauser J, Allen M. Serum $\mathrm{Mg}$ levels in asthmatic patients during acute exacerbation of asthma. Am J Emerg Med. 1992;10:1-3.

[13] De Valk HW, Kok PT, Struyvenberg A, van Rijn HJ, Haalboom JR, Kreukniet J. Extracellular and intracellular magnesium concentrations in asthmatic patients. Eur Respir J. 1993;6:1122-5.

[14] Ali AA, Bakr RM, Yousif M, Foad RE: Assessment of serum magnesium level in patients with bronchial asthma. Egyptian Journal of Chest Diseases and Tuberculosis (2015) 64,535-539.

[15]Alamoudi O.S., Hypomagnesaemia in chronic, stable asthmatics: prevalence, correlation with severity and hospitalization, Eur. Respir. J. 16 (2000) 427-431.

[16] B.G. Vittal et al, A study of magnesium and other serum electrolyte levels during nebulized salbutamol therapy, J. Clin. Diagn. 4 (2010) 3460-3464.

[17]H.A. Mohammad, M.T. Abdulfttah, A.O. Abdulazez, et al, A study of electrolyte disturbances in patients with chronic stable asthma and with asthma attacks, Egypt. J. Chest Dis. Tuberc. 63 (2014) 529-534.

[18]Konrad M, Hou J, Weber S, Dotsch J, Kari JA, Seeman T, Kuwertz-Broking E, Peco-Antic A, Tasic V, Dittrich K, Alshaya $\mathrm{HO}$, von Vigier RO, Gallati S, Goodenough DA, Schaller A. CLDN16 genotype predicts renal decline in familial hypomagnesemia with hypercalciuria and nephrocalcinosis. J Am Soc Nephrol. 2008;19:171-181

[19]Alamoudi OS. Hypomagnesaemia in chronic, stable asthmatics: Prevalence, correlation with severity and hospitalization. Eur Respir J. 2000;16:427-31.

[20] Satoshi T, Yamamoto A, Tomonaga S, Funaba M, and Matsui T. "Magnesium Deficiency Induces the Emergence of Mast Cells in the Liver of Rats." J Nutr Sci Vitaminol JNSV Journal of Nutritional 
Science and Vitaminology 59.6 (2013): 56063.

[21]Malpuech-Brugère C, Nowacki W, Daveau M, Gueux E, Linard C, Rock $\mathrm{E}$,Inflammatory response following acute magnesium deficiency in the rat. Biochim Biophys Acta. 2000 Jun 15; 1501(2-3):91-8. [22] Kazaks AG, Uriu-Adams JY, Albertson TE, Shenoy SF, Stern JS. Effect of oral magnesium supplementation on measures of airway resistance and subjective assessment of asthma control and quality of life in men and women with mild to moderate asthma: a randomized placebo controlled trial. J Asthma 2010; 47: 83-92.

[23]Zervas E, Loukides S, Papatheodorou G, Psathakis

$\mathrm{K}$, Tsindiris K, Panagou P, Kalogeropoulos N. Magnesium levels in plasma and erythrocyte before and after histamine challenge. Eur Respir J. 2000;16(4):621-625. [24]Sopnajothi S., Sooriyakumar, Vadivelmurugan S., Ravikumar T. , Purusothaman: Prognostic Implication of Serum Magnesium Levels in Patients with Chronic Stable Asthma. IOSR Journal of Dental and Medical Sciences (IOSR-JDMS) (May. 2017), Volume 16, Issue 5 Ver. VIII PP 56-60. 